\title{
Natural Zeolites as Sustainable and Environmental Inorganic Resources over the History to Present
}

\author{
Eva Chmielewská* \\ Department of Environmental Ecology, Faculty of Natural Sciences, Comenius University, \\ llkovičova 6, Mlynská dolina B2, 84215 Bratislava, Slovakia \\ Email: chmielewska@uniba.sk (E. C.)
}

\begin{abstract}
Zeolites synthetic as well as natural, based on their beneficial properties and economic value, represent for a long time recognized industrial commodities. Natural zeolites are highly porous, hydrated aluminosilicates with a rigid crystalline structure and a network of interconnected tunnels and cages (such as honeycomb). Total pore volume of some natural zeolites reaches up to $35 \%$. Their structures consist of a three dimensional framework, having a negatively charged lattice. The negative charge is balanced by cations, which are exchangeable with certain cations from aqueous or gaseous media. Based upon these facts and according to a new definition, zeolites are also clathrates or inclusion compounds, able to host various guest substances in their versatile structures and thus enhance their adsorption potential to broaden range of pollutants.
\end{abstract}

Keywords zeolites, alginate, surfactants, carbonization, clinoptilolite-rich tuff, ion exchange, surface functionalization

\section{Introduction}

Since 1756, when the famous Swedish mineralogist Axel F. Cronstedt recognized firstly new mineral species in the northern copper mine Svapparaara and called them "zeolite", it has passed more than 260 years. Actually, this newly discovered mineral found in the vugs and cavities of basalt rocks was stilbite. For many years thereafter, zeolites represented for mineralogists only a jewellerous commercial interest, just on the base of their spectacular crystals, arising from the volcanic matrix. ${ }^{[1,2]}$

The word "zeolite" has Greek roots and means "boiling stones" (zein = to boil and lithos = stone), deriving from the visible loss of water, noted when the natural zeolite was heated in the "mineralogist's" blowpipe. Volcanic rocks containing natural zeolites, i.e., hydrated aluminosilicate minerals, have been mined worldwide perhaps for more than thousand years, mostly for use as cement and building stones. Nevertheless, it is believed that zeolitic tuff may have been used already by the ancient Romans and Indians 2000 B.C. for construction of houses, roads, sewage channels, aqueducts, temples and pyramids. According to one of the life theory hypothesis, natural zeolites may even catalyze the reactions of ammonia with carbon oxides to aminoacids and thus probably generate initial protein precursors for the first living organism, leading up to the higher forms of complex matter along the biological world evolution. ${ }^{[1-5]}$

Nowadays, zeolites are becoming widely used as alternative materials in areas, where adsorptive applications and thermal and radiation resistance are required. Since several decades, they have been intensively studied based on their high efficiency in removing trace quantities of pollutants such as heavy metal ions, ammonium, radionuclides, some colour entities, and many others noxious substances. The characteristics and applications of zeolites have been reviewed by many authors. ${ }^{[4]}$ High ion-exchange capacity and relatively high specific surface area, and more importantly their relatively low prices, make zeolite also today an attractive adsorbent. Their price is about $0.03-0.12 \$ / \mathrm{kg}$, depending on the quality of the mineral. Another advantage of natural zeolites over synthetic resins is their ion selectivities generated by their rigid porous structures.

Most of natural zeolites in sedimentary rocks were formed from volcanic ashes or other pyroclastics by a reaction of amorphous aluminosilicate glasses pervaded with pore water. Others originate from an alteration of pre-existing feldspars, feldspathoids, biogenic silica or poorly crystalline clay minerals. The factors controlling whether a zeolite or a clay mineral predominates is still unsufficiently understood. However, temperature, pressure, reaction time, alkalinity and dissolved salts in pores solution seem to be the dominant factors. From the about 80 known types of natural zeolites, at least 20 have been reported from repositories in zeolitically altered rocks. However, only the following nine (analcim, chabazite, clinoptilolite, erionite, ferrierite, heulandite, laumontite, mordenite and phillipsite) are known to occur in repositories large enough to mine in Figure 1.

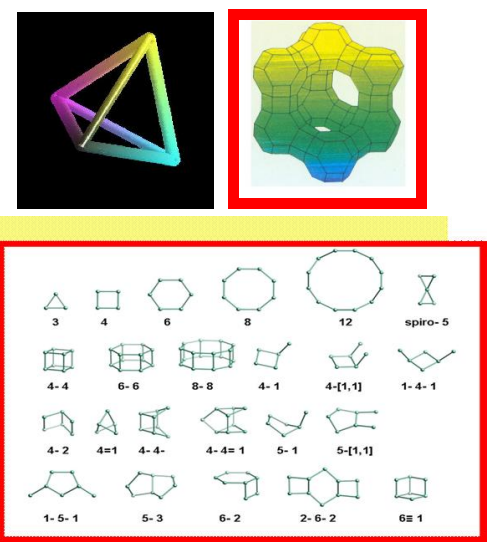

Figure $1 \mathrm{TO}_{4}$ tetrahedra as the basic units of zeolites, where $\mathrm{T}$ is Al or Si. The structure of the faujasite. The traditional secondary building units (SBU subunits) of zeolite structures (from upper left to lower down). 


\section{Minireview}

Currently, over thousand occurences of zeolite minerals have been reported predominantly from sedimentary rocks of volcanic origin in more than 50 countries of the world, e.g., USA, Mexico, Cuba, Chile, Argentina, South Korea, Japan, China, New Zeland, South Africa, Tanzania, Kenya, Iran, Israel, Bulgaria, Romania, Hungary, Slovakia, Slovenia, Serbia, Ukraine, Croatia, Georgia, Turkey, Italy, and so on. Most of the mines are designed for clinoptilolite or mordenite exploitation, but also in less extent the chabazite or phillipsite are mined. Permanently improved geophysical and remote-sensing techniques are helpful in the further zeolite exploration. Mining a zeolitic ore is relatively simple compared to mining most of the other mineral commodities. Zeolite-bearing formations are generally at, or close to the surface, and require the removal of only small amounts of over burden to expose the ore. The raw material is then processed by crushing, drying, powdering and screening. Some beneficiation processes for zeolites have been developed, respectively. However, these are mostly not employed commercially. Natural zeolite minerals used for ion exchange applications are usually sold as screened products in the 10 to 50 mesh (equivalent to $2 \mathrm{~mm}$ and $0.3 \mathrm{~mm}$, respectively) size range. ${ }^{[8]}$

With the beginning of millenium, natural zeolites (especially clinoptilolite-rich tuff) have been upgraded to a commodity of great potential, more or less due to the progress permanently reached by their marketing, e.g., as building stone, as lightweight aggregate and pozzolans in cements and concretes, in the uptake of radioactive cesium and strontium from nuclear waste and fallouts, as soil amendments in agronomy and horticulture, in the removal of ammonia from municipal, industrial or agricultural waste and drinking waters, as an energy supplier in solar refrigerators, as dietary supplements in animal diets and as zeoponic substrate for growing plants on space missions to their recent application in the healing of human cuts and wounds. Some update or other of zeolitic applications related to cleanup processes are available already by hundreds. Finally, based upon all the zeolite (clinoptilolite-rich tuff) examinations for various kind of aqueous pollutants removal, it may be concluded that this natural resource can be considered as an alternative and cost-effective adsorption material either with surface treatment or without, depending on type of water pollutants to be removed. ${ }^{[9,10]}$

\section{Clinoptilolite as the Most Abundant and Useful Zeolite}

Certainly, the most abundant and most frequently studied zeolite is clinoptilolite, a mineral of the heulandite group. The crystal structure of the HEU-type zeolites is characterized by a 3-dimensional aluminosilicate framework consisting fundamentally of secondary building units (SBU) of the 4-4-1 type, formed by tetrahedral primary building units (PBU). Its characteristic tabular morphology shows an open reticular structure of easy access, formed by open channels of 8-10 membered rings (Figures $1-3$ ).

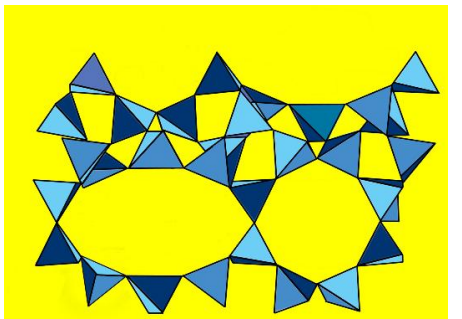

Figure 2 Principle of tetrahedras connection in the clinoptilolite structure.

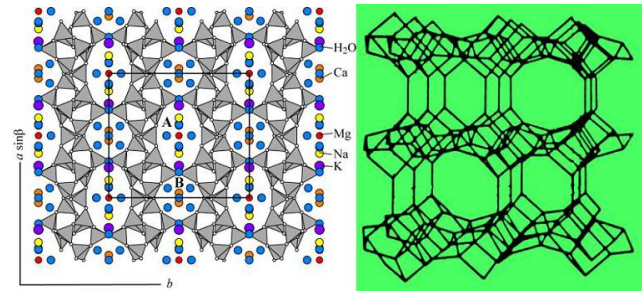

Figure 3 The crystal structure of clinoptilolite. Typically clinoptilolite contains 4 to 7 cations per unit cell. Clinoptilolite-K is the most widespread. $\mathrm{Mg}$ occurs in almost all clinoptilolites. As in other zeolites, $\mathrm{Fe}$ is most likely $\mathrm{Fe}^{3+}$ and resides in tetrahedral sites (left). Principal sketch of clinoptilolite crystal topology (right).

Clinoptilolite framework contains narrow 4- and 5-membered rings in parallel sheets arrangement, as well as broad 8- and 10-membered rings constituting intraframework micropores (channels with the size of $3.3 \times 4.6 \AA ; 3.0 \times 7.6 \AA$ and $2.6 \times 4.7 \AA$ ) perpendicularly to these parallel sheets, capable to host extra-framework exchangeable cations in association with mobile water molecules.

The origin and use of the name clinoptilolite ("oblique feather stone") has a convoluted history. The crystals were firstly identified by Pirsson in 1890 as "crystallized mordenite", based solely on chemical analysis. The platy habit and optical properties led Schaller in 1932 to conclude that it was a ptilolite (ptilo- from Greek alludes downy, finally fibrous nature of mineral), which was named by Cross and Eakins already in 1886 for materials occurring at the Table Mountain in Colorado (USA) and later found to be mordenite. Schaller named these crystals clinoptilolite, despite that its morphology was very similar to heulandite. Based on X-ray diffraction data later on, the heulandite and clinoptilolite were determined as isostructural. Finally, Mason and Sand proposed a new definition for clinoptilolite in 1960 based on alkali-dominant and high Si/Al compositions regarding to the isostructural heulandite. According to them, thereafter the minerals with the same framework topologies, but with the Si/Al less than 4.0 , were classified as heulandite and with the Si/Al ratio higher than 4 as clinoptilolite. ${ }^{[11-14]}$

Clinoptilolite was formed mostly as a devitrification product of volcanic glass in tuffs, which mean basically the consolidated pyroclastic rocks. This devitrification occurred usually when the glass was in contact with saline waters. This mineral is mostly found in the form of small crystals $0.1-100 \mu \mathrm{m}$ associated with clays and other silicate and aluminosilicate phases of similar density (Figure 5). However, even centimeter scale simple crystals can grow in cavities of igneous rocks from natural hydrothermal solutions. The relatively "open" structure of HEU-type zeolites, with a total pore volume of $35 \%$, enhances the sorption properties of these microporous solids, especially toward gaseous molecules such as dinitrogen, water, carbon monoxide, ammonia, methanol, methane and pyridine, which are small enough to enter the channels. However, the chemical composition of framework (the Si/Al ratio, in the range 3-5) modulates the ion-exchange properties of the zeolites expressed as cation-exchange capacity (CEC, which can theoretically reach $330 \mathrm{meq} / 100 \mathrm{~g}$ ). The rather low Si/Al ratio and the consequently increased CEC render HEU-type zeolites advantageous for binding dissolved cations from aqueous solutions. ${ }^{[15-20]}$ In the hydrated form of heulandites, the most prominent extra-framework cation sites used to be labelled by a letter indicating the $A, B$ or $C$ channel and a subsequent number (Figure 4). In a dehydrated state, the tetrahedral rings may collapse, even tetrahedral connections may break and other 
connections may develop and therefore different extra-framework sites become important. Because the $C$ channel connects the $A$ and $B$ channel parallel essentially, all extra-framework sites are also a part of the $C$ channel. In the $A$ channel, there are three potential cation sites on the mirror plane, bonds to $2-5$ oxygen sites of the tetrahedral framework and various $\mathrm{H}_{2} \mathrm{O}$ molecules in opposite direction. Cations of different size or degree of hydration may adjust their bonding distance to the framework by displacement either toward $\mathrm{C}$ or $\mathrm{A}$ channels, whereby particularly preferring small cations. For large cations, there are accessible mostly the B-sites in the mirror planes, linked with up to four bonds to framework oxygen. The clinoptilolite unit cell is monoclinic c-centered and usually characterized on the basis of 72 oxygen atoms and 20 water molecules, with $\mathrm{Na}^{+}, \mathrm{K}^{+}, \mathrm{Ca}^{2+}$ and $\mathrm{Mg}^{2+}$ as the most common charge-balancing cations. According to Figure 4, the type of 2D microporous channel system was firstly characterized for heulandite. Channels $A$ (10-member rings) and $B$ (8-member rings) are parallel to each other and to the c-axix of the unit cell, while $C$ channels (8-member rings) run along the $\alpha$-axis intersecting both $A$ and $B$ channels. The elliptic-shaped 8- and 10-member rings that form the channel system are non planar and cannot be simply dimensioned. Based upon their pore dimensions, channels $A, B$ and $C$ and intersections $I_{1}$ and $I_{2}$ can be classified as ultramicroporous. The existence of larger sized pores in natural zeolites may be due to the existence of impurities or by partial removal of constituents of the zeolitic matrix during acid leaching. The type, number and location of the chargebalancing cations residing in the A, B or C channels influence the selectivity and uptake rate of pollutants to be removed by clinoptilolite. $^{[21]}$
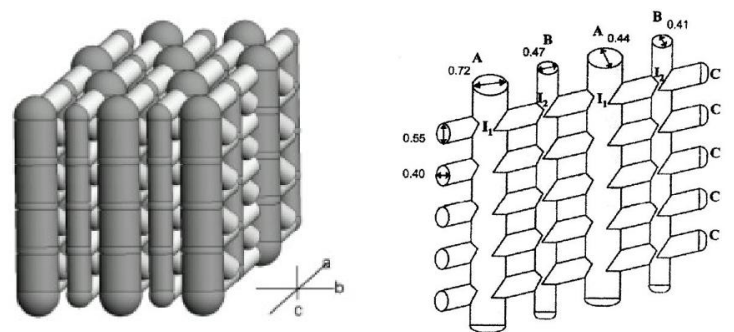

Figure 4 Columnar model of 2-dimensional channel arrangement of HEU framework (left). The clinoptilolite structure according to Yamanaka et al. ${ }^{[28]}$ depicting channels A, B and C and intersections $I_{1}$ and $I_{2}$. Numbers represent pore dimensions in $\mathrm{nm}$ (right).

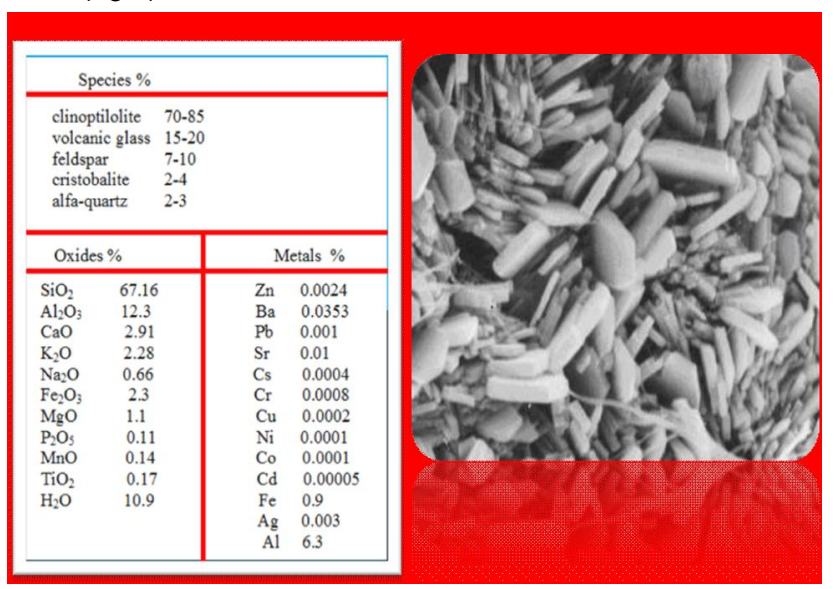

Figure 5 The mineralogical and chemical composition of the clinoptilolite-rich tuff from the deposit Nižný Hrabovec (Slovakia). Tabular crystal shapes (clinoptilolite surface morphology under Scanning Electron Microscope)-right.
Clinoptilolite-based materials are interesting due to the occurrence of diverse phenomena during the sorption process, these phenomena being of both fundamental and practical importance. Clinoptilolite is not the most well known zeolite species so far, however, it is one of the most useful natural zeolites. The occurence of mineral as fine-grained crystals in massive beds allows it to be mined and used in applications, where large amounts of materials are required. Also, clinoptilolite proves high ability to withstand thermal regeneration and resistance to attrition losses during the handling and therefore is used in many applications such as chemical sieve, gas absorber, dust and flue gas cleaning agent, feed and food additives, odor control agent, filtration cartrige for aquarium and as water filter or adsorbent in municipal or surface waters treatment, filler by rubber, paper and wood processing and as a component for cement and concrete manufacturing. Clinoptilolite has been successfully used for several decades more or less as an additive to feed for cows, pigs, horses and chickens, because it is able to absorb toxins out of feed originating from molds and microscopic parasites during the animal digestion. Many applications exploit the ion exchange properties, which are attractive for agronomy, horticulture and soil remediation, where the zeolite may be added to chemical fertilizers to improve the soil chemical and physical properties for plant growth, to increase fertilizer efficiency as well as to reduce the leaching of nutrients. ${ }^{[22]}$

\section{Dopping of New Functional Groups onto Surface of Clinoptilolite-Rich Tuff to Enhance Its Sorption Potential}

For the water purification, besides the metal-containing nanoparticles, carbonaceous materials and dendrimers, also the zeolites are being evaluated as the most progressive functional and nanosized materials of the millenium. Because zeolites in natural form possess restricted sorption abilities, mostly the surface of clinoptilolite-rich tuff used to be treated or modified with various substances in order to enhance or upgrade its removal potential toward environmental pollutants. By such a way so called "composite or hybridized zeolite based adsorbents" are synthesized. ${ }^{[23,24]}$

By other words, an organic-zeolite composite adsorbent termed as a hybrid material too, may be defined hereto as a combination of a polymerous substance immobilized onto surface of the inorganic, e.g., zeolite carrier to avail advantages of both zeolitic and polymerous constituents as well. ${ }^{[25]}$

On the base of the huge abundance in the country, price easily accessibility and feasibility, cost effectiveness and due to the sufficiently large surface area, rigidity and surface functionality, clinoptilolite-rich tuff of domestic origin used to be applied many times for such as interface carrier. Actually, the intent was to tailor such components immobilized onto zeolitic rock, which improve considerably the water purification and pollutants removal efficiency, while acquiring the necessary adhesion and aggregation forces toward the colloidal and many other water impurities. ${ }^{[8-10]}$

According to foreign literature, ${ }^{[22]}$ natural zeolite of clinoptilolite type was beneficiated with several cationic surfactants, such as hexadecyltrimethylammonium chloride (HDTMA), cetylpyridinium chloride (CPC) and others, by using the sol-gel method. In our research, octadecylammonium (ODA) surfactant was selected for this treatment as inland economically accessible product, applying with a long tradition for domestic bentonite hydrophobization. This surfactant consists of the long straight hydrocarbon chains $(18 \mathrm{C})$ with the polar ammonium head at the one end of their tails (Figures 6). This sol-gel process is suitable and most common wet route for the synthesis 
of hydrophobized, i.e., surfactant covered clinoptilolite-rich tuff. The process is based on the condensation of molecular precursors in solution, originating a "sol", while further condensation leads to the final wet "gel". Because these reactions are performed at room temperature, further heat treatment is needed to acquire the final hydrophobization product. The main parameters that influence the kinetics, growth reactions, hydrolysis, condensation reactions and consequently the structure and properties of the gel are solvent, temperature, nature, concentration of the salt precursors employed, $\mathrm{pH}$ and agitation. In principle, the negative charged clinoptilolite framework used to be easily modified via the addition of positive charged octadecylammonium (ODA) surfactant. Petrochemicals, i.e., mostly hydrophobic pollutants, based on both-sites interaction mechanism trough partitioning and intercalation into surfactant's chains, are mostly removed onto ODA-monolayer treated zeolite, which imparts a high degree of hydrophobicity, while negative charged anionic pollutants are preferentially removed onto ODA-bilayer modified zeolite based on the electrostatic forces. ${ }^{[26,27]}$ Bilayer configuration causes positive charge of the zeolitic surface, resulting in a higher affinity for negatively charged anionic contaminants that is attributed to surface anion exchange. Possible arrangement of the both types of surfactant molecules at the zeolitic surface presents Figure 6.
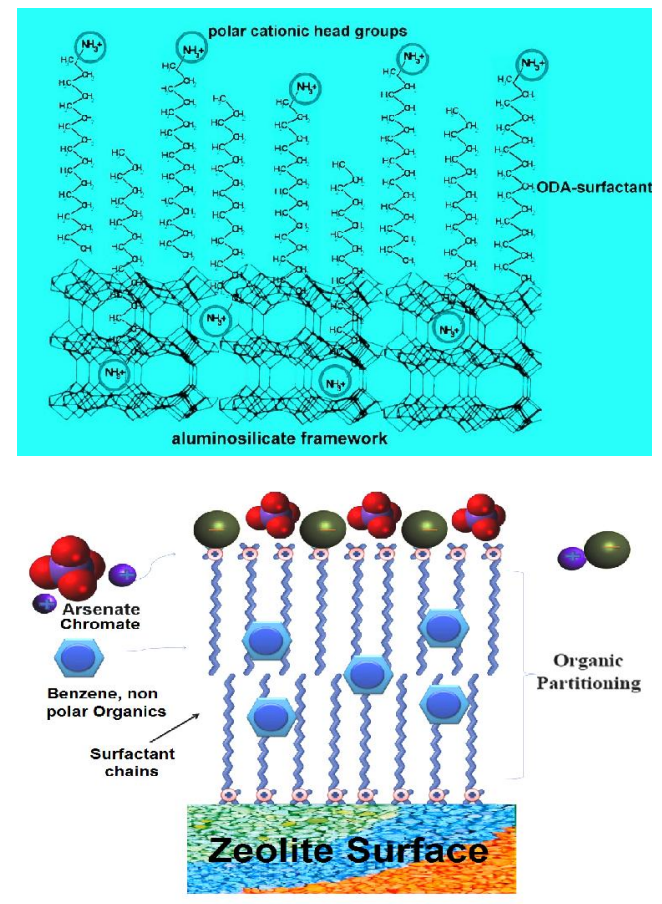

Figure 6 Sketch of surfactant mono- and bilayer used for zeolitic surface modification (downwards).

By another sol-gel method, the biopolymeric alginate used to be crosslinked with powdered zeolite to alginate-zeolitic pellets in order to promote the native zeolite performance and prepare more efficient amphoteric product suitable for specific water decontamination. Alginate is a copolymer of the isomers of mannuronic and guluronic acids, stabilizing mostly suspensions and colloids in various media. Flexible component, i.e., alginate biopolymer with a rigid component (powdered) zeolite, is usually crosslinked with $\mathrm{Fe}(\mathrm{III})$ and $\mathrm{Ca}(\mathrm{II})$ salts. While $\mathrm{Fe}(\mathrm{III})$ cationic sites of pelletized biosorbent remove the negative oxyanionic pollutants in water during the cleanup process by electrostatic forces, Ca cations of biosorbent matrix are responsible for ion exchange and thus toxic cations removal (Figure 7). ${ }^{[29]}$

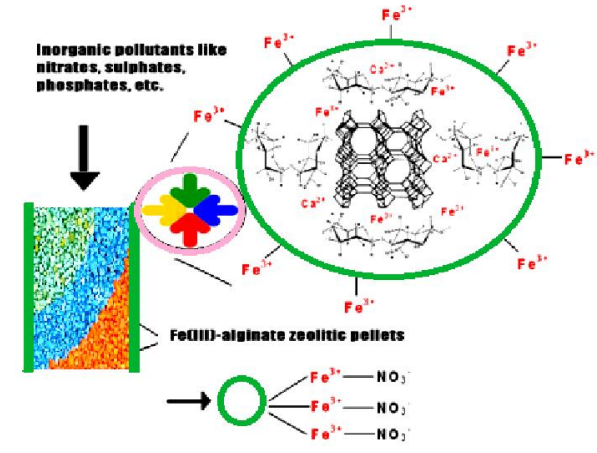

Figure 7 Principal sketch of the synthesized Fe(III) alginate pelletized clinoptilolite-rich tuff and its function for inorganic anions uptake.

Also, carbonization process in pyrolysis chamber, which combusted organic waste material and reached the maximum temperature of $450{ }^{\circ} \mathrm{C}$, was used for the carbonization of clinoptilolite-rich tuff surface. Subsequently, surface of carbonized zeolite was investigated by detailed Scanning Electron Microscopy, under which individual carbon nanotubes (CNT) as a new allotropic carbon modification besides an amorphous carbon was identified. Fe-metal and reduced Fe-metal oxides nanoparticles, present in the domestic zeolite in the concentrations around $1 \%$ of $\mathrm{Fe}$ (total), fulfilled probably the nucleation role for a potencial CNT growth. Based upon the EDS measurements, the individual carbon nanotubes were of about $0.35-0.4 \mathrm{~nm}$ thickness and consisted of over 100 graphene layers. The inside diameter of those carbon nanotubes reached the values of 4 up to $40 \mathrm{~nm}$. The length of tubes was estimated for about $1 \mu \mathrm{m}$. Adsorption ability of carbonized clinoptiloliterich tuff, which resembled to activated carbon, was successfully validated toward phenol, thereafter. ${ }^{[30,31]}$

Materials designed using components derived from biological sources such as collagen, chitosan, threedimensional polymeric hydrogels such as surfactants, alginate, plant proteins and polysaccharides have also been investigated thoroughly for use in environmental adsorbents fabrication and zeolitic adsorption improvement. Since natural biomaterials possess some advantages over their synthetic counterparts, such as their capability to be environmentally viable and thus recognized by the living microenvironment. Since the beginning of $21^{\text {st }}$ century, several types of hydrogels with excellent mechano-chemical properties have been developed through applying different synthesis routes. However, biomimetic sol-gel strategy remains still the most frequently used synthesis route in advanced adsorbents fabrication. ${ }^{[4-6]}$

When iron is stored as a nanoparticle of iron oxide (ferrihydrite) inside the protein cage ferritin (Fn), it is completely sequestered and rendered inert. Thus, the encapsulation and sequestration of the iron oxide nanoparticle in biological systems highlights its tremendous potential also for use as a synthesis platform for material design.

From understanding direct biomineralization in $\mathrm{Fn}$, scientists developed a model for surface-induced metal oxide formation and have used this as a guiding principle for the synthesis of metal oxide nano-particles in other natural or engineered architectures. ${ }^{[7-10]}$ Biomimetic sol-gel synthesis was also used for $\mathrm{FeO}(\mathrm{OH})$ zeolite preparation. Based on strongly alkalic conditions during the process, the surface groups of zeolite probably lost their hydrogen ions and became negatively charged. A considerably part of $\mathrm{Fe}$ neutral species as well as $\mathrm{Fe}(\mathrm{III})$ ionic clusters originating from alkalic $\mathrm{FeO}(\mathrm{OH})$ solutions were probably deposited outside zeolite framework, 
because the clinoptilolite structure contains channels with the size of $0.33 \times 0.46 \mathrm{~nm} ; 0.3 \times 0.76 \mathrm{~nm}$ and $0.26 \times 0.47 \mathrm{~nm}$ not sufficient large for their entrance. ${ }^{[12,21]}$ They might associate then with ion-exchange reactions or surface complexation, which occur through the removal or the addition of hydrogen atom. A broad variety of physically and chemisorbed Fe species in zeolite rock may serve then in enhanced toxic metals removal from waters via intercalation, electrostatic interaction and other sorption processes. Main advantages of metals removal onto $\mathrm{FeO}(\mathrm{OH})$ zeolite might be the relatively low capital costs and therefore applicability to a large volume of waters, especially to highly acidic mine waters. ${ }^{[32]}$

Ammonia is the most commonly occurring nitrogenous pollutant in the current water bodies, which by subsequent dissolved oxygen depletion, significantly contributes to the typical eutrophication processes. Synthetic ion exchangers for water decontamination used to be characterized as effective but relatively expensive absorbents, generally containing some functional groups with insoluble structures, which show high affinity toward the nutrients such as $\mathrm{NH}_{4}{ }^{+}, \mathrm{NO}_{3}{ }^{-}, \mathrm{PO}_{4}{ }^{3-}$. Despite of that, zeolitc molecular sieves and their ion exchange properties, as well as availability and cost, are the major factors that make natural zeolites commercially more attractive for this purpose. Especially, clinoptilolite seems a competitive solution for ammonia removal from waters, because it proves better selectivity to some monovalent over divalent cations. By other words, a decreasing of aluminum content in the zeolite structure increases the average distance between the adjacent anionic sites of the framework, and thus the difficulty of a single divalent cation to satisfy the field of two adjacent anionic sites (Figure 8).

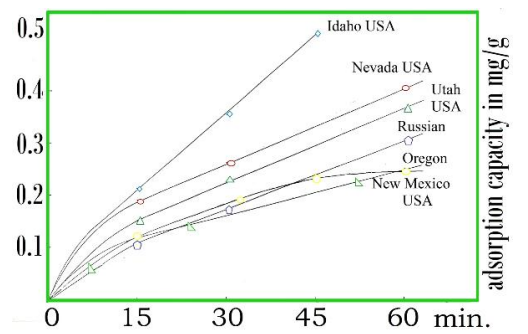

Figure 8 Kinetics of ammonium removal onto various deposits zeolites from aqueous solutions.

Consequently, the preference of the zeolite for divalent cations falls down and that for univalent cations arises. In general, while a zeolite favors the least hydrated ion, the solution phase favors the most highly hydrated ion. Therefore, the large, poorly hydrated cations are preferred in "weak" field zeolites, i.e., that with lower aluminum content and thus lower framework charge density, which is the case of clinoptilolite. Obviously, the ion exchange affinity is often found to be in agreement with the hydrated ionic radius and follows more or less bellow patterns: ${ }^{[33]}$

$$
\mathrm{Cs}^{+}>\mathrm{Rb}^{+}\left(\mathrm{NH}_{4}^{+}\right)>\mathrm{K}^{+}>\mathrm{Na}^{+}>\mathrm{Li}^{+}
$$

and for divalent cations as:

$$
\mathrm{Ba}^{2+}>\mathrm{Sr}^{2+}>\mathrm{Ca}^{2+}>\mathrm{Mg}^{2+}
$$

Based on the high selectivity of clinoptilolite toward ammonium ion, several pilot or even industrial water treatment facilities in some countries have been constructed. ${ }^{[34-36]}$ During the autumn 1986, the zeolite ion exchange pilot installation (ZIEPI) with a hydraulic loading rate of $900 \mathrm{~L} / \mathrm{h}(\sim 13$ Bed Volumes BV/h) was situated also at the field experimental facility of Water Re- search Institute in the closed vicinity of Bratislava. This pilot facility treated the tap water, which was enriched by ammonium chloride to the initial concentration of $1 \mathrm{mg} \mathrm{NH}_{4}{ }^{+} / \mathrm{L}$. One column filled with $56 \mathrm{~kg}$ of grained zeolite was able to treat 85 cubic meters of drinking water with enhanced ammonium concentration up to the limited value of $0.5 \mathrm{mg} / \mathrm{L}$, what means that the 4 days operated zeolite filter removed from the whole treated volume of water $81 \mathrm{~g}$ of ammonia. Similar operation with the same hydraulic loading rates through the zeolite beds as by the drinking water purification was also used for ammonia removal of mixed tannery and sewage sludge wastewater at Shoe Manufactury Wastewater Reclamation Plant in Otrokovice (former Czechoslovakia) in the 1987 (Figure 9). A higher ammonium concentration in wastewater (in average $50 \mathrm{mg} / \mathrm{L}$ ) increased the ion exchange capacity of zeolite column considerably (approximately 10-times higher in regard to the drinking water purification). ${ }^{[37-39]}$

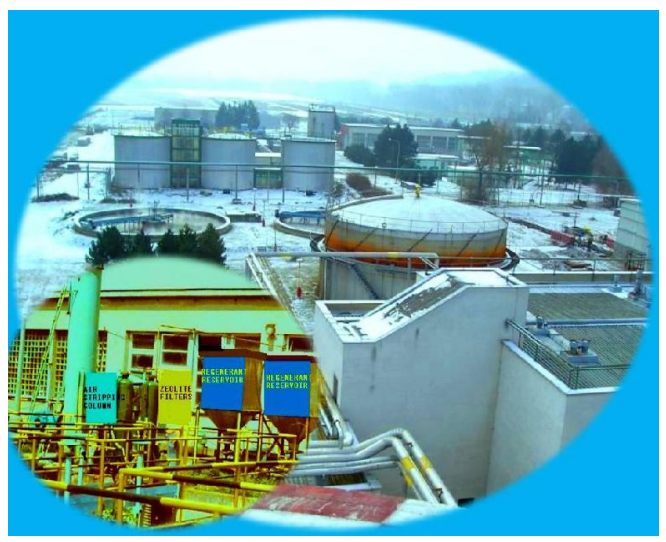

Figure 9 Pilot ammonia removal with clinoptilolite-rich tuff of mixed tannery and sewage wastewater at Shoe Manufactury Wastewater Treatment Plant in former Czechoslovakia in the 1987 (process of zeolite ion exchange incl. regeneration and air stripping by mass closed loop operation).

\section{Conclusions and Perspectives}

Based upon all the zeolite (clinoptilolite-rich tuff) examinations for various kind of aqueous pollutants removal, it may be concluded that this natural resource can be considered as an alternative cost-effective adsorption material either with surface treatment or without, depending on type of water pollutants. Mostly surface untreated clinoptilolite-rich tuffs compete with the other natural materials or even waste products, purchased on the markets for economic prices, because mining a zeolitic ore is relatively simple compared to mining most of the other mineral commodities. Natural zeolite minerals used for ion exchange applications are usually sold as screened products in the 10 to 50 mesh $(0.3 \mathrm{~mm}$ up to $2 \mathrm{~mm}$ ) size range. To broaden their adsorption potential for various water pollutants, using the above discussed treatment methods would certainly increase the price of this commodity, based on chemicals and energy consumption, however, by far not so dramatically as by currently marketed commercial products.

\section{Acknowledgement}

This project was supported by the APVV agency of Slovakia under the code: SK-SRB-2016-0001-Zeolite-based adsorbents for environmental remediation.

\section{References}

[1] Cronstedt, A. F. Observation and Description of an Unknown Kind 
of Rock to be Named Zeolites (in Swedish), Kongl. Vetenskaps, Acad. Handl., Stockholm, 1756, Vol. 17, pp. 3-120.

[2] Dyer, A. An Introduction to Zeolite Molecular Sieves, John Wiley \& Sons, Chichester, New York, p. $144,1988$.

[3] Breck D. W. Zeolite Molecular Sieves. Structure, Chemistry and Use. John Wiley \& Sons., New York, London, Sydney, Toronto, 1974, pp. 1-771.

[4] Pansini, M. Natural Zeolites as Cation-Exchangers for Environ-mental Protection, Mineralium Deposita, 1996, p. 31, 6, pp. 563-575.

[5] Chelishchev, N. F.; Volodin, V. F.; Krjukov, V. L. Ionoobmennye svoistva Prirodnych vysokokremnistych ceolitov (in Russian), Moskva-Nauka, 1988, pp. 1-128.

[6] Armbruster, T. Clinoptilolite-heulandite. Applications and Basic Research. In Studies in Surface Science and Catalysis 135. Eds.: Galarneau, A.; Di Renco, F.; Fajula, F.; Vedrine, J. Elsevier Science, pp.14-26, 2001.

[7] Mumpton, F. A. Plenary Lecture, The 3rd Congreso Mexicano de Zeolitas Naturales in Zacatecas, 2003, November 9-12; Book of Proceedings, Azcapotzalco, Mexico, pp. 3-4, 2003

[8] Gottardi, G.; Galli, E. Natural Zeolite. Minerals and Rocks, Springer Verlag, Berlin, Heidelberg, New York. Tokyo, 1987.

[9] Eds.: Ming, D. W.; Mumpton, F. A. Zeolite '93. Occurrence, Properties and Utilization of Natural Zeolites. Conference Program and $\mathrm{Ab}$ stracts based on papers presented at Zeolite ' 93 in Boise, Idaho; June 20—28, 1993. ICNZ Brockport. New York, 1993, pp. $1-622$.

[10] Svetich, R. Long-Term Use of Clinoptilolite in the Treatment of Sewage at Tahoe-Truckee Sanitation Agency, Truckee, California, Zeolite '93, Occurrence, Properties and Utilization of Natural Zeo lites. A Conference Program and Abstracts based on papers pre sented at Zeolite '93 in Boise, Idaho, June 20-28, 1993. Eds.: Ming, D. W.; Mumpton, F. A. ICNZ Brockport, New York, 1993, pp. $1-622$.

[11] Wilson, S. T.; Lok, B. M.; Messina, C. A.; Cannon, T. R. J. Am. Chem. Soc. 1982, 104, 11146

[12] Pirsson, L. V. Am. J. Sci. 1890, 140, 232.

[13] Schaller, W. T. Am. Mineral. 1932, 17, 128.

[14] Coombs, D. S.; Alberti, A.; Armbruster, T.; Artioli, G.; Colella, C.; Galli, E.; Grice, J. D. Mineral. Mag. 1998, 62, 533.

[15] Akizuki, M.; Kudoh, Y.; Nakamura, S. Can. Mineral.1999, 37, 1307.

[16] Alberti, A. Tschermaks Mineral. Petrogr. Mitt. 1975, $22,25$.

[17] Alberti, A.; Vezzalini, G. Tschermaks Mineral. Petrogr. Mitt. 1983, $31,259$.

[18] Chmielewská, E. Environmental Zeolites and Aqueous Media. Examples of Practical Solutions. Bentham Science, 2014, p. 220.

[19] Baerlocher, C.; Meier, W. H.; Olson, D. H. Atlas of Zeolite Framework Types, $6^{\text {th }}$ Edition, Elsevier, 2007.

[20] Marantos, I.; Christidis, G. E.; Ulmanu, M. Zeolite Formation and
Deposits. Handbook of Natural Zeolites. Eds.: Inglezakis, V. J.; Zorpas, A. Bentham Science, pp. 28-51, 2012.

[21] Hernándes, M. A.; Rojas, F.; Lara, V. H. J. Porous Mater. 2000, 7, 443.

[22] Mercurio, M.; Sarkar, B.; Langella, A. Modified Clay and Zeolite Nanocomposite Materials, Environmental and Pharmaceutical Applications, Elsevier, Amsterdam, Netherlands.

[23] Steed J. W.; Turner, D. R.; Wallace, K. J. Core Concepts in Supramolecular Chemistry and Nanochemistry, John Wiley \& Sons, 2007.

[24] Wu, F. C.; Tseng, R. L. J. Colloid Interface Sci. 2005, 294, 21.

[25] Chmielewská, E. An Update of Zeolitic and Other Traditional Adsorption an Ion Exchange Materials in Water Cleanup Processes, Natural Zeolite Handbook, Chapter 3.9, pp. 274-285, Bentham Science Publisher, New York, 2012.

[26] Chmielewská, E.; Jesenák, K.; Gáplovská, K. Chem. Commun. 2003, 68, 823.

[27] Chmielewská, E.; Sabová, L.; Gáplovská, K.; Čaplovičová, M. Kuwait J. Sci. Eng. 2008, 35, 1.

[28] Yamanaka, S.; Malla, P. B.; Komarneni, S. Zeolites 1989, 9, 18.

[29] Chmielewská, E.; Sabová, L.; Peterlik, H.; Wu, A. Brazilian J. Chem. Eng. 2011, 28, 63.

[30] Chmielewská, E.; Sabová, L.; Jesenák, K. J. Therm. Anal. Calorim. 2008, 92, 567.

[31] Chmielewská, E., Sabová, L., Wu, A. Aranyosiová, M., Velič, D. Annales Chemia Universitatis M. C. Sklodowska 2007, 4, 35.

[32] Chmielewská, E.; Tylus, W.; Drábik, M.; Majzlan, J.; Kravčak, J.; Williams, C.; Čaplovičová, M.; Čaplovič, L'. Microporous Mesoporous Mater. 2017, 248, 222.

[33] Chmielewská, E.; Lesný, J. J. Radioanal. Nucl. Chem. 2012, 293, 535.

[34] Jorgensen, T. C.; Weatherley, L. R. Water Res. 2003, 37, 1723.

[35] Liberti, L.; Boari, G.; Passino, R. Water Res. 1978, 13, 65.

[36] Svetich, R. Long-Term Use of Clinoptilolite in the Treatment of Sewage at Tahoe-Truckee Sanitation Agency, Truckee, California, Eds.: Ming, D. W.; Mumpton, F. A. Zeolite '93, Occurrence, Properties and Utilization of Natural Zeolites, A Conference Program and Abstracts based on papers presented at Zeolite ' 93 in Boise, Idaho, June 20-28, 1993, ICNZ Brockport, New York, NY, 1993.

[37] Chmielewská-Horváthová, E.; Konečný, J.; Bošan, Z. Acta hydrochimica et hydrobiologica 1992, 20, 269.

[38] Chmielewská-Horváthová, E.; Konečný, J.; Bošan, Z. Technology for Wastewater Treatment in Tannery Processing Plants, CS-Patent 02604-89, No. 274068, 1989.

[39] Chmielewská, E. Desalin. Water Treat. 2012, 41, 335.

Received January 2, 2019 Accepted January 19, 2019 